Научная статья

УДК 341

doi: 10.17586/2713-1874-2021-4-55-63

\title{
COPYRIGHT PROTECTION VS FREEMOVEMENT OF GOODS WITHIN THE INTERNAL MARKET OF THE EU
}

\author{
Ljuben Kocev ${ }^{I}$ \\ ${ }^{1}$ Ss. Cyril and Methodius University, Skopje, Republic of Macedonia, ljuben.kocev@eccf.ukim.edu.mk, \\ https://orcid.org/0000-0002-5039-6643 \\ Article in English
}

\begin{abstract}
The article is about identification of statistical patterns in the field of trademarks and service marks registration. To identify patterns, official statistical data provided in the relevant state collections were used. The analysis of dynamic changes in the certificates and the filled applications allowed us to indicate positive conclusions about the intellectual property registration in Russia. The article also provided the hypothesis of the dependency between the number of organizations in a certain region and the number of registered trademarks and service marks. It was concluded that the hypothesis put forward about the presence of a possible dependence between the number of organizations in a certain region and the number of registered trademarks and service marks was partially confirmed. There really is a pattern, that is, with an increase in the number of organizations in a certain region, the number of registered trademarks and service marks increased, but it was not possible to build a clear mathematical model of dependence.

Keywords: intellectual property rights, copyright, free movement of goods, European Union, Internal Market

For citation: Kocev L. Copyright Protection vs Free Movement of Goods within the Internal Market of the EU. Ekonomika. Pravo. Innovacii. 2021. No. 4. pp. 55-63. http://dx.doi.org/10.17586/2713-1874-2021-4-55-63.
\end{abstract}

\section{ЗАЩИТА АВТОРСКИХ ПРАВ ПРИ ПЕРЕМЕЩЕНИИ ТОВАРОВ НА ВНУТРЕННЕМ РЫНКЕ ЕС}

\author{
Любен Косев ${ }^{1}$ \\ ${ }^{1}$ Университет Св. Кирилла и Мефодия, Скопье, Республика Северная Македония \\ ljuben.kocev@eccf.ukim.edu.mk, https://orcid.org/0000-0002-5039-6643 \\ Язык статьи - английский
}

Аннотация: Автор статьи рассматривает проблему международной торговли объектами интеллектуальной собственности. В основе исследования лежит проблема возникающего противоречия между свободным перемещением товаров и услуг и обеспечением защиты авторских прав. В качестве региона исследования выбран Европейский Союз. В статье исследуется авторское право и его отношение к правам собственности, что является корнем противоречий, возникающих между двумя принципами. Затем следует краткий обзор принципа свободного перемещения товаров и его применения на внутреннем рынке ЕС. Кроме того, автор оценивает, как и когда правообладатели ограничиваются в осуществлении своих прав из-за принципа свободного перемещения товаров. Рассмотрены условия, при которых авторы и государства-члены имеют законное право запрещать перемещение товаров для обеспечения эффективной защиты авторских прав.

Ключевые слова: права интеллектуальной собственности, авторское право, свободное перемещение товаров, Европейский Союз, внутренний рынок

Ссылка для цитирования: Косев Л. Защита авторских прав при перемещении товаров на внутреннем рынке ЕС (на англ.) // Экономика. Право. Инновации. 2021. № 4. С. 55-63. http://dx.doi.org/10.17586/2713-18742021-4-55-63.

Introduction. Ensuring effective and efficient protection of copyright is necessary not only because the creation brings personal satisfaction for the author, but also because the author draws economic benefits from its exploitation. The lack of effective and efficient protec- tion has a negative impact, as it reduces the motivation of authors to create in the future. Consequently, granting the author exclusive rights over its creation helps spur innovation and promotes competition on the market. This means that the author can derive economic benefits 
from the exploitation of his work by allowing others to use it in return for remuneration, and the author has the sole right to prevent any unauthorized use of his work. However, in this manner, authors can also restrict and limit the owners of the copyright protected works in the usage or disposition of the works. In some instances, these restraints can even amount to violation of the principle of free movement of goods, which is one of the pillars on which the Internal Market and the European Union are established. It is therefore necessary to strike a balance between the effective protection of intellectual property rights (IPR) and the principle of the free movement of goods, since in absolute terms the two principles are colliding.

The idea of this article is to consider a possible conflict between the principle of free movement of goods across state borders and effective copyright protection within the EU. The article based on the principle of gradual comparative analysis, starting from the objects of car law and ending with issues of possible litigation. One of the objectives of the study was to prepare an overview of the conditions for the free movement of goods in the EU. This could give an exact answer to the question in which cases it is possible to speak of infringement of intellectual property rights. Thus, it is logically possible to determine the situations in which the protection of intellectual rights is required, regardless of customs regulations.

This study carried out in the framework of an international youth conference under the auspices of the World Customs Organization. The mission of this study is to improve existing procedures for the international movement of goods.

Methodology. The primary methods used in the paper are the comparative and analytical methods. This approach is required due to several factors. Firstly, copyright protection is primarily granted at national level, therefore, it is necessary to make a comparative review and analysis of the accepted national solutions. On the other hand, aspects of copyright are also regulated at international level, and consequently comparation of national vis-à-vis international legislation is also required. The analytical method is primarily used in the evaluation and interpretation of the various sets of rules and provisions regulating questions of copyright. In addition, there are other methods which are used to support the findings. In order to shed light on the stages of development of the level of protection of copyright, and define the framework of the principle of the free movement of goods, it is necessary to utilize the historical method. The descriptive method is used as supportive method for the analytical method as it lays out the state of play in the intersection of the two relevant topics of the paper.

\section{Results.}

1. Copyright.

Intellectual property rights (IPR) objects are creations of the human mind [1].

In the broadest sense, IPR divided in two major categories: industrial property rights, copyrights, and other related rights. While protection of industrial property is subject to previous administrative procedure for approval by a competent state authority (e.g. National Offices for Industrial Property), protection for copyright is not conditioned upon prior approval, and is granted the moment the work has been created. In this paper the focus is only on copyright. In light of this, innovators have to make strategic choices when deciding in which territory they will seek protection of their innovation depending of the attractiveness of the market, and the level of protection, which granted, whereas authors enjoy worldwide protection but do not have any influence over the rights granted in various national legislations.

Copyright is the closest to human nature, since its origin is associated with the normal course of human life. People tend to create objects of copyright at random, not always realizing that they should take care of proper protection of the exclusive rights to these IP objects.

According to WIPO, copyright is «a legal term used to describe the rights that creators have over their literary and artistic works» [2]. As already noted, protection of copyright is necessary not only because the exploitation of the work has economic benefit for the author, but also because in absence of efficient protection, authors and innovators would be disincentive to create in the future which would ultimately lead to standstill in the economic development. It is therefore necessary to stimulate authors and innovators by granting them exclusive rights over their creations. In this regard, copyright is similar with property rights, parti- 
cularly ownership right due to the fact that both are subjective type of rights which have an erga omnes effect i.e. they are absolute in nature and give the bearer of those rights' entitlement «towards all». For the most part, there is no collision between the two types of rights, since they can be established upon an object and coexist independently from one another. Namely, the establishment of a property right upon one object does not exclude a copyright embedded within that object, and conversely, the existence of a copyright cannot completely limit the property right. Even more, in practice it is often the case that the owner of an object, on which an intellectual creation is fixed, and the copyright holder of that creation are completely different persons. This is in fact manifestation of the economic exploitation of the copyright. In line with this is the most significant distinction between the two types of rights.

Namely, while ownership rights have to be established on a particular object and are always associated with that particular object, copyright originate from intellectual creations which are immaterial. While copyright can be fixed on various objects, or works, and material manifestations so that they can be receptive to our senses, it exists independently from the medium on which it is fixed. Another important feature of the intellectual creations is that they are not exhausted by one manifestation and their use and reproduction is possible over and over again. For example, a book, i.e. the content of the book, can be reproduced, owned, and available for usage for millions of people. The ability and speed to reproduce these creations nowadays is even greater given the digitalization and development of the information technologies. Because of the way works can be reproduced and disseminated, copyrights are even more susceptible to violation. While in the past such activities were easier to detect and prevent primarily because of the medium on which they were fixed (e.g. printed book, movie on a $\mathrm{CD}$, music album on a cassette etc.), due to the evolution of the internet and digital technologies detection and prevention has become much more difficult.

However, despite the fact that copyright and ownership right are not mutually exclusive and can co-exist, there are situations where a conflict can arise between the copyright holder and the ownership right holder, primarily as to whether and to what extent can the copyright holder interfere and restrict the owner of the copyright protected work in the exercise of his property rights over that work. If these situations are analyzed from the context of national law, the solution is straightforward as in most cases national laws contain provisions regulating the relation between copyright and property rights. However, the situation is more complex when it comes to potential copyright infringement in the international context, and especially in the context of the EU.

In international context there are a number of treaties and conventions regulating copyright. The Berne Convention from 1886 is the first and most significant instrument addressing copyright. It is based on three principles: national treatment, automatic protection and independence of protection [3]. Beside the economic rights of the author, the Convention also recognizes some moral rights [4]. The WIPO Copyright Treaty [5] is a special agreement under the Berne Convention that deals with the protection of works and the rights of their authors in the digital environment. The WCT also recognizes computer programs and databases as works that enjoy copyright protection (WCT, Article 4 \& 5). The WTO's Agreement on Trade-Related Aspects of Intellectual Property Rights (TRIPS) sublimates obligations arising from various IPR treaties under the auspices of the WTO. In relation to copyright, the TRIPS agreement encompasses the main three principles established in the Berne Convention and additionally imposes an obligation of "most-favored-nation treatment", under which advantages accorded by a WTO Member to the nationals of any other country must also be accorded to the nationals of all WTO Members (TRIPS, Article 4).

Let's turn to the regulatory issues in the European Union. These international treaties are applicable by way of their ratification by the EU Member States, but also by their acceptance of the EU itself, since both the EU as a union and its Member States on their own, are members to the WTO (Membership Information, 2020). In addition to these treaties, the EU has its own copyright legislation. While the founding treaties have very limited obligations related to copyright and IPR in general, the EU copyright acquis consist of 11 directives and two regulations to this date, the most significant being Di- 
rective 2001/29/EC on the harmonization of certain aspects of copyright and related rights in the information society (Info Soc Directive).

International treaties and conventions set only minimum standards and criteria that should be accepted by contracting states, and do not contain detailed provisions on the content of copyright. The purpose of principles embodied within the international treaties and conventions is primarily to provide equal treatment to authors within a country, regardless of their nationality or residence. For example, under the principle of national treatment established within the Berne Convention, nationals of member states of the Berne Union, in the other member states shall enjoy the same rights as nationals of those states [6]. Similar provisions and principles have been adopted in other international treaties and conventions. However, while this principle prohibits discrimination in respect of the nationality, it does not address the situation where a national of a union member enjoys a protection within his home state, which does not exist in other member state. The fact that a member state does not recognize a right of an author which he enjoys in his home state or in other member state, does not mean that the member state violates the principle of national treatment, since the state does not recognize that right even to its own nationals.

Despite the fact that there have been attempts to regulate and harmonize copyright for more than a century, to this date it still remains enforceable primarily in national context. In this regard both copyright and ownership right exist in the context of national law, i.e. both type of rights are territorially restricted. The holders of these rights can enjoy them since they are granted and protected by the national legislation. However, unlike the content of the ownership right, which is more or less universally accepted, copyright varies in its scope and content from one state to another. The fact that some rights are envisaged and exist within one national law does not mean that they are recognized in other legislations, and even if they are, differences still might occur regarding their scope. If the IPR protected works are on the territory of one state, the national law of that state shall be taken into account to determine the existence of infringement, but where the IPR protected works are in different states, or are in constant circulation on the market (e.g. the European Internal Market), the question which arises is to what extent can the copyright holder seek protection for infringement of a right.

Differences like these cause problems both at global and at regional levels. While regional integration is an ongoing trend within the past decades and recognition and protection of IPR plays an integral part of those processes, at present, unification in this regard seems impossible, even at the level of the EU, given the fact that there are significant differences among Member States as well.

2. European Internal Market rules.

From the outset of the creation of the European Economic Community, the principal goal was the establishment of customs union and single market. The main objective of the Internal Market is elimination of any obstacles which prevent free movement within the borders of the EU, while the main objective of the customs union is elimination of custom duties, physical, technical and economic barriers between Member States. The Treaty on the Functioning of the European Union (TFEU) explicitly provides that the free movement of goods, services, persons and capital is ensured in the internal market (TFEU, Article 26). While the EU institutions have made significant progress in this area, one of the few remaining sectors where harmonization is still lacking are taxation and IPR's.

The principle of free movement of goods is regulated in Articles 28-37 TFEU. The provisions are divided into 2 groups: provisions pertaining to the establishment of a customs union (TFEU, Article 28-33) and provisions pertaining to the removal of quantitative restrictions (TFEU, Article 34-37). Regarding the customs union, Article 30 of the TFEU contains a general provision prohibiting customs duties on imports and exports of goods between Member States and any taxes having such effect. In regard to provisions on the removal of quantitative restrictions, Article 34 and 35 TFEU respectively, explicitly prohibit quantitative restrictions on imports and exports between Member States as well as any measure which would have the same effect. These general provisions are interpreted as an absolute prohibition by Member States to impose restrictions both on goods produced in a Member State and on goods which are not produced in a Member 
State but have been imported in a Member State and thereby are eligible for circulation within the Internal Market.

However, the principle of free movement of goods is not unlimited and absolute, and restrictions may imposed in some extraordinary circumstances. Article 36 of the TFEU expressly provides that Member States may prohibit the export, import or transit of goods if the prohibition justified on the basis of: safety;

- public morality, public order or public

- protecting the health and life of people, animals or plants;

- protection of national treasures of artistic, historical and archaeological value;

- protection of industrial and commercial property.

However, it is important to note that these exceptions used by Member States in a restrictive manner and can't be used in a discriminatory manner.

The Court of Justice of the European Union (CJEU) has set very high standards for States to use to such exceptions [7]. These exceptions are listed in an exhaustive way and generally the free movement of goods cannot be restricted on any other grounds. Interestingly, despite the possibility for restricting the free movement of goods for the protection of industrial property rights, the TFEU does not envisage such restriction for copyright protection. Namely, from the plain wording of Article 36 it can be deducted that the drafters have made a distinction between industrial property rights and copyright as IPRs but have not attached the same significance to both types of rights. However, this formulation has been subjected for interpretation before the CJEU in several instances. Firstly, in the Deutsche Grammophon case (1971), the Court held that the wording "industrial and commercial property" should be interpreted extensively so as to encompass copyright as well [8]. This standpoint has been reconfirmed later on in the cases of GEMA (1981) and Coditel (1982).

3. Free movement of goods vs protection of copyright.

As already discussed, one of the major problems in relation to copyright is the tension between the principle of free movement of goods on one hand, and the territorial exclusivi- ty granted to copyright holders in national legislations on the other. From a legal point of view, the tension arises because the principle of free movement of goods requires a single market without any barriers, while the approach of national copyright regulation of Member States leads to territorial segmentation. Therefore, the key issue is how to strike a balance that will take into account the interests of copyright holders, but at the same time will not restrict the free movement of goods as one of the fundamental principles of the EU.

a. Limits to copyright.

Much of the debate over the balance between the protection of IPR and the free movement of goods focuses on whether IPR should exist in all circumstances, i.e. be absolutely unlimited, or should they be restricted in some way. The center of this debate is to what extent IPR extend outside of the state which grants them [9]. This is the exhaustion of rights doctrine, or the first sale doctrine. According to this doctrine, the first sale or transfer of ownership of the original or a copy of the copyright protected work from the author is deemed to have exhausted his commercial rights in respect of that work. That would mean that in essence, unless otherwise provided by law, further resale, lending, rental and other forms of commercial exploitation cannot be controlled or restricted by the author of the work (WIPO, n.d.). However, when it comes to exhaustion of rights, it is important to note that the concept of absolute limitation is not universally accepted. Namely, there is a debate over which commercial rights of the author are exhausted after the first sale, as well as the territory in which the ownership of the copyright protected work has to be sold or transferred for the doctrine to be effective. Thereby, while the exhaustion of rights doctrine is accepted in most national legislations, it is not equally treated and interpreted.

Regarding the rights which are exhausted, today it is generally accepted that after the first sale or transfer of ownership of a work or a copy, the author loses the right to prohibit their further distribution. This principle is accepted in Article 6 of the WCT. This was also one of the fundamental principles of the EU which is reflected in Articles 36, 101 and 102 of the TFEU [6]. The exhaustion of the distribution right is also accepted in the Macedonian national legis- 
lation. Namely, Article 29 paragraph 5 of the Law on Copyright and Related Rights (LCRR) [10] stipulates that the right of distribution within the territory of the country "shall be exhausted by the first sale or other type of first transfer of ownership right of an original or copy of a copyright protected work».

Unlike the exhaustion of the distribution right, the first sale or transfer of ownership does not exhaust the right for lending which is also vested in the author. In the EU, this issue has not been regulated explicitly in either of the founding treaties. However, the CJEU has made a significant impact through the interpretation of the EU acquis. In the case of Warner Bros. v. Christiansen (1988) [11] the court found that companies which sell videocassettes for movies in other Member States can invoke copyright to prevent their resale and renting after the cassettes have been sold. Warner Bros. had a copyright which was recognized in several Member States for a movie reproduced on cassettes for resale and rent and marketed it throughout several states. Christiansen purchased one of those copies and advertised copies for sale and rent in Denmark, which was not one of the markets targeted by Warner Bros. The CJEU found that regardless of the fact that Warner Bros. had selected which are its targeted markets, its lending and rental rights were not exhausted at the sale of the cassette within the particular market, and therefore, it could assert copyright protection. This case is one of the catalysts for the adoption of the Rental and Lending Rights Directive (Directive 2006/115/EC) [12]. The Macedonian LCRR follows the same approach and stipulates that exhaustion through first sale would not apply to the rights of importation, rental and lending (LCRR, Article 29 (5)) [10].

Exhaustion of the right of importation largely depends on the concept of territorial exhaustion accepted by the state of import. There are three types of concepts of exhaustion which may be distinguished: national, regional and international exhaustion. The concept of national exhaustion does not allow the copyright holder to control further distribution of the work put on the domestic market by the holder with his consent. However, the copyright holder could still oppose the importation of works that are advertised and sold abroad on the basis of the right of importation [13]. This is the most traditional concept which was widely accepted for very long time. However, it has been considered a protectionist concept, since it prohibits the possibility for parallel imports, and it can lead to market segmentation and price differentiation [13]. This concept of national exhaustion is adopted into the Macedonian LCRR as it stipulates that the right of distribution in the national territory is exhausted with the first sale or transfer of ownership, however such exhaustion does not apply among others, to the right of importation [10].

In the case of regional exhaustion, the first sale of the copyright work by the copyright holder exhausts any rights over these given products not only domestically, but within the whole region (WIPO, n.d.). Unlike national exhaustion, the copyright holder cannot prohibit the importation of works released for circulation in any of the countries in the region. The region can be composed of member states of economic associations, areas or unions (e.g. EU or EEA). Regarding the EU, there is a consensus that it adopts the concept of regional exhaustion [14, 9]. However, it is important to note that the principle does not explicitly derive from the founding treaties of the EU, but has been established, again through the work of the CJEU. In the case of Micro Leader Business v. Commission (2000), the Court held that the sale and marketing of a work outside of the EU does not exhaust the author's right of importation, but that such right is only exhausted if the sale or transfer of ownership has occurred within the Internal Market. This view is further transposed in the Info Soc Directive [15].

Lastly, according to the concept of international exhaustion, the rights of the copyright holder are exhausted once the work has been sold or the ownership has been transferred in any part of the world. This means that when a copyright protected work or a copy of that work has been sold in any part of the world, the author's distribution or import rights will be exhausted. The EU is not yet ready to accept this concept, but maybe there will be a shift in the attitude in the future [9]. While this concept may be too progressive and forward thinking for regional unions and organizations, there are countries which have accepted it. In this regard, states are free to adopt different concepts of exhaustion for different types of IPR [13]. For ex- 
ample, Switzerland adopts the concept of national exhaustion in terms of patents, while in the case of trademarks and copyright it adopts the concept of international exhaustion [14].

The exhaustion of rights is a way to limit the copyright holder's ability to influence and restrict the rights of the owner of the copyright protected work. However, as it is evident, this limitation is not absolute, and there are instances where the author may still impose restrictions. While it is almost universally accepted that the author may not restrict the distribution right, it is also more or less accepted that the author can restrict the lending right. Depending on the territorial aspect of the exhaustion of rights, the author may also restrict the importing right, which in these instances is inextricable from the right of distribution.

\section{b. Safeguarding copyright.}

IPR protection systems safeguard the rights vested in the author and stimulate intellectual creations in the future. In some cases, in order to provide effective and efficient copyright protection, it is necessary to restrict the free movement of goods. As already elaborated, the EU founding treaties provide that in certain situations the free movement of goods may be restricted if the restrictions are imposed in order to achieve a higher social objective. However, beside the enumeration of grounds under which the free movement of goods can be restricted in Article 36 TFEU, there is lack of provisions for their application. In absence of more specific guidelines, the CJEU again plays a major role. One of the most significant cases in respect of copyright is the Donner case (2012) [16].

In this case an Italian company Dimensione had been selling furniture replicas of the famous German Bauhaus school. The company used marketing promotion methods specifically targeted to customers from Germany. Mr. Donner, a German citizen, through his own freight forwarding company, took over the furniture and paid for it to Dimensione and then received payment for the furniture increased for shipping costs by end-buyers in Germany. In the period when the furniture was sold, in Italy some of the works did not enjoy copyright protection, while the others did enjoy protection by the law, but under Italian-case law it was not enforceable in practice. On the other hand, in Germany unlawful distribution or copying of copyright protect- ed work amounts to criminal offence. While the Munich District court found that Mr. Donner is guilty since he committed the criminal offence of aiding and abetting the unlawful distribution of copyright protected works, Mr. Donner appealed firstly on the ground that the «distribution to the public» is most closely connected with the transfer of ownership which occurred in Italy, and not the physical delivery, which occurred in Germany, and secondly that any other interpretation would lead to artificial partitioning of the Internal Market.

The Federal Court of Justice referred to the CJEU for a preliminary ruling. In its ruling, the CJEU placed an emphasis on interpreting «distribution to the public» by sale under Article 4(1) of the Info Soc Directive. The court found that distribution encompasses series of acts ranging from the conclusion of a contract of sale to the performance by delivery to a member of the public. However, when a trader explicitly targets consumers in the country and thus enables the consumers of that country to effectively obtain the works by providing a delivery and payment, it is considered that distribution takes place in the country where the consumers are located. Further on, the CJEU found that indeed the prohibition and sanctioning by the national criminal law is violation of the free movement of goods under Article 34 TFEU, however such restriction can be justified under Article 36 TFEU.

While this decision of the CJEU is to some extent expected, it still holds great significance. Although the court was more focused on defining the concept of distribution of copyright protected works, what is significant is the interpretation that Member States may undertake copyright protection measures and even criminal sanctions as long as such protection applies in a non-discriminatory manner. What remains to be seen is whether this ruling will initiate further harmonization in the field of copyright and IPR in general.

Conclusions/ Recommendations. The effective and efficient copyright protection depends not only from the rights which copyright holders enjoy under international treaties, but also from the way they are enforced in practice. As absolute rights which have an erga omnes effect, copyright gives their holder exclusivity over the exercise of those rights. However, these 
rights are not unlimited, and in some instances, they can be restricted. The principle of the free movement of goods is, one of the cornerstones of functioning of the Internal Market, and is the most powerful driving force of the EU's economic development. However, when seen in absolute terms the territorial aspect of copyright protection and the principle of free movement of goods are mutually restrictive. It is therefore necessary to strike a balance between the two principles, enabling Member States to provide effective copyright protection, but at the same time ensuring that this would not lead to the imposition of barriers within the Internal Market.

Today it is accepted that some rights of right holders are limited, primarily on the principle of exhaustion of rights. In this regard, there is growing agreement that the right to distribute exhausted at the first sale or transfer of property by the copyright owner or with his consent. The right to import is also restricted, although the restriction depends on the concept of territorial exhaustion adopted by the national state or, in the case of the EU, by the community as a whole. On the contrary, there is a uniform approach whereby certain rights, such as lease and loan rights, are not exhausted in the first sale or transfer of ownership of copyrighted works.

Given the fact that full harmonization and

\section{References}

1. Dabovic Anastasovska, Pepeljugoski J.V. Intellectual Property Rights. Akademik. Skopje. 2012

2. Copyright Definition. WIPO. Available at: https://www.wipo.int/copyright/en/

3. Intellectual Property Reading Handbook. WIPO, Geneva. 2004

4. Berne Convention for the Protection of Literary and Artistic Works (as amended on September 28, 1979). WIPO. 1979. 58 p.

5. WIPO Copyright Treaty (1996). WIPO. Available

https://wipolex.wipo.int/en/text/295166

6. Dabovic Anastasovska, Pepeljugoski J.V. Copyright. «Iustinianus Primus», Faculty of Law, Skopje. 2015.

7. Goebl P.J. «The Interplay Between Intellectual Property Rights and Free Movement of Goods in the European Community», Fordham unification of intellectual property rights within the EU seems impossible in the near future, there may still be situations where national legislation can used as a territorial wall, which may impede the principle of free movement of goods. However, it is important that clear rules exist at the community level as to what may constitute a legitimate interest of a Member State in restricting the free movement of goods. In the absence of rules on the grounds for restricting free movement in accordance with Article 36 of the TFEU, the CJEU seems to be the most important institution providing interpretation that leads to the gradual harmonization of certain aspects of copyright. This role of the CJEU been repeatedly confirmed over the years, when judicial practice has acted as a supporter of the adoption of directives. While it is undeniable that the case law approach to identifying copyright-related issues has been very successful (given the fact that CJEU deals with specific cases rather than legislation that focuses on a large number of hypothetical scenarios), the question Remains to what extent CJEU alone may be the leading source of energy in the copyright harmonization process.

This research will continued in the next scientific research in the field of the development of customs academic research.

Intellectual Property. Media and Entertainment Law Journal. 1993. Volume 4. pp. 125-130.

8. C-78/70, Deutsche Grammophon Gesellschaft

$\mathrm{mbH}$ v. Metro-SB-GrolmArkte $\mathrm{GmbH} \&$ Co. KG, [1971] E.C.R. 487, [1971] 10 C.M.L.R. 631.

9. Tudor J. Intellectual Property, the Free Movement of Goods and Trade Restraint in the European Union. The Journal of Business, Entrepreneurship \& the Law. 2012. Volume 6. Issue 1. pp. 46-101.

10. Law on Copyright and Related Rights. Official Gazette. No. 140/10, 51/11, 147/13, 154/15 and $27 / 16$.

11. C-158/86, Warner Bros. Inc. v. Christiansen, [1988] E.C.R. 2605

12. Directive 2006/115/EC of the European Parliament and of the Council of 12 December 
2006 on Rental Right and Lending Right tion». Journal of Intellectual Property Law. and on Certain Rights Related to Copy- 2011. Volume 19. pp. 203-230.

right in the Field of Intellectual Property, OJ L 15. Directive 2001/29/EC of the European 376, 27.12.2006.

13. Taubman A. et.al. (eds.). A Handbook on Parliament and of the Council of 22 May 2001 the WTO TRIPS Agreement. Cambridge University Press, Cambridge. 2012.

on the harmonization of certain aspects of copyright and related rights in the information society, OJ.L 167, 22.6.2001.

14. Pope A. «A Second Look at First Sale: An 16. C-5/11, Donner, [2012] ECLI:EU:C: International Look at U.S. Copyright Exhaus- 2012:370. 